\title{
INVESTIGATION OF LEAD REMOVAL FROM DRINKING WATER USING DIFFERENT SORBENTS
}

\begin{abstract}
Lead is a heavy metal with strong toxic properties. This chemical element is found in wastewater and sometimes in drinking water. The article deals with the removal of lead(II) ions from polluted water using a sorption process to determine the most effective sorbent for the removal of lead(II) ions. Three sorbents were used in the research: clay, sapropel, and iron sludge. All three sorbents investigated reduce the concentration of lead(II) ions in water: clay efficiency was of 65.7-90 \%, sapropel of 94.3-100 \%, and iron sludge of 84.3-97\%, depending on sorbent type and contact duration. The research has shown that the most effective way to remove lead(II) ions from the test water is sapropel. Using different amounts of sapropel $\left(1,2,3,4,5,6 \mathrm{~g} / \mathrm{dm}^{3}\right.$ and 0.1 , $\left.0.2,0.4,0.5,0.6,0.8 \mathrm{~g} / \mathrm{dm}^{3}\right)$ and different duration of contact $(30,60,90,120$ and 150 minutes), the concentration of lead(II) ions in the test water after purification did not exceed the permissible values for drinking water $\left(10 \mu \mathrm{g} / \mathrm{dm}^{3}\right)$, so that the lowest sapropel content of $0.1 \mathrm{~g} / \mathrm{dm}^{3}$ can be used for sorption. Lead(II) ions are most effectively removed when contact time is $30 \mathrm{~min}$.
\end{abstract}

Keywords: lead, water, sorbent, adsorption, clay, sapropel, water treatment iron sludge

\section{Introduction}

Lead is one of the most dangerous heavy metal for ecosystems. This heavy metal has strong toxic properties. Lead is a highly poisonous metal having effect on almost every body organ. The nervous system is the mostly affected target in lead toxicity $[1,2]$. Lead tends to accumulate in the body and can cause adverse effects: damage to the central nervous system, 5-10\% of the lead in the gastrointestinal tract is absorbed by adults, and $50 \%$ by children, by inhalation, $80-100 \%$ of lead gets into the blood, it is accumulated in the hair, nails and bones [3,4]. Lead is one of the most dangerous components of wastewater. Heavy metals enter the environment in large quantities from natural and anthropogenic sources. Natural lead pollution occurs from volcanic explosions and forest fire. Non-natural sources are from human activity - from the industry and transportation [5]. Road transport emits, along with exhaust gas, as much as $75 \%$ of lead contained in petrol. Renovation of old steel structures can result in large amounts of lead dust. The metallurgical industry, lead-processing companies and fuel plants also contribute to the environmental pollution with lead compounds. Other sources are from manufacturing batteries, coal burning, type casting, and in older houses and buildings [5-7]. By burning

\footnotetext{
${ }^{1}$ Department of Chemistry and Bioengineering, Faculty of Fundamental Sciences, Vilnius Gediminas Technical University, Vilnius, Sauletekio ave. 11, Lithuania, phone +370 52512465

${ }^{2}$ Department of Environmental Protection and Water Engineering, Faculty of Environmental Engineering, Vilnius Gediminas Technical University, Vilnius, Saulètekio ave. 11, Lithuania, phone +370 52744725

*Corresponding author: ramune.albrektiene@vgtu.lt
} 
lead-containing waste - capsules, tubes, synthetic materials, anti-corrosive paints - the pollutants get into the air and then settle on the soil and enter the water bodies. Major exposure pathways of pollution also include intake of lead from consuming lead-contaminated water and food. Food can become contaminated with lead due to the soil and water in the growing environment, or materials used in processing or cooking or the containers used for storage. The water from lead soldered plumbing, leaded polyvinyl chloride (PVC) products can be polluted with lead [5]. It has been found that in China, Poland, Japan, Singapore, India and Cambodia the levels of lead in drinking water exceed the permissible values $\left(10 \mu \mathrm{g} / \mathrm{dm}^{3}\right.$ according to Directive 98/83/EC [8], $15 \mu \mathrm{g} / \mathrm{dm}^{3}$ according to World Health Organization) [4, 8-11]. Lead concentration in water can be reduced by nanofiltration, membrane filtration [12]. Adsorption is often used for lead removal [13]. Adsorption using nanosorbents has a higher efficiency in removing chemical elements [14].

Various sorbents are used to remove heavy metals: biomass, activated carbon, red clay, zeolites, magnetite, aluminium, carbon nanotubes, chitosan, copper, iron, manganese and zinc oxides, aluminium sorbents, bentonite [13, 15-18]. Oak bark, mahogany bark, lignin, rice shells, clay, modified peat, bamboo pulp, sawdust, active sewage sludge, modified wool, palm tree waste fibres, saffron flower waste etc. can be used as sorbents too [19-22].

A lot of lead removal techniques are used in the world, the most common one being the adsorption process, but there is a lack of research of the uses of sorbents that are easy to obtain and cheap, such as clay, sapropel and iron-saturated sludge. Three cheap and available adsorbents - clay, sapropel, and iron sludge - were used in the lead(II) adsorption study.

Clay has good sorption properties. The adsorption capacity of clay depends on the negative charge of clay minerals. The negative charge contributes to the ability of clay to adsorb positive metal ions. The sorption capacity of clay depends on pore size and surface area [23-25]. Typically, unmodified clay is used in adsorption, but clay adsorption capacity may be increased by chemical modification [14].

Sapropel is a muddy sediment or sediment formed on the bottom of fresh, standing water bodies. Organic matter consists of lignin-humus complex, carbohydrates and bitumen [26]. Sapropel is characterized by the ability to sorb organic substances and heavy metals from solutions [27].

Iron sludge occurs as the result of the preparation of drinking water, where the iron surplus is removed from groundwater to the quantity allowed by the Lithuanian hygiene norm in water treatment facilities [28]. Iron oxides have adsorptive properties. This property has been investigated by the use of iron sludge for the removal of phosphorus from domestic wastewater and for removal of organic compounds from water [24, 28].

The purpose of this article is to investigate the dependence efficiency of the removal of lead(II) ions from drinking water on contact time, adsorbent dose, and solution $\mathrm{pH}$ using three different sorbents (clay, sapropel, and iron sludge).

\section{Materials and methods}

According to one investigation of the groundwater quality in Prey Nop district of Cambodia, one district in coastal area, it was observed that concentration of iron and lead in groundwater are higher than permissible values [8] (Table 1). 
Quality data of groundwater in Prey Nop district, Cambodia

\begin{tabular}{|c|c|}
\hline Parameters & Amount \\
\hline $\mathrm{pH}[-]$ & 5.25 \\
\hline Electrical conductivity $[\mu \mathrm{S} / \mathrm{cm}]$ & 32.2 \\
\hline Turbidity $[\mathrm{NTU}]$ & 6.95 \\
\hline Dissolved oxygen $\left[\mathrm{mg} / \mathrm{dm}^{3}\right]$ & 2.52 \\
\hline Total dissolved solid $\left[\mathrm{mg} / \mathrm{dm}^{3}\right]$ & 1660 \\
\hline Ammonia $\left[\mathrm{mg} / \mathrm{dm}^{3}\right]$ & 0.05 \\
\hline Nitrite $\left[\mathrm{mg} / \mathrm{dm}^{3}\right]$ & 0.001 \\
\hline Iron $\left[\mathrm{mg} / \mathrm{dm}^{3}\right]$ & 0.958 \\
\hline Lead $\left[\mathrm{mg} / \mathrm{dm}^{3}\right]$ & 0.0702 \\
\hline
\end{tabular}

The test water was deionized water contaminated with lead(II) ions with the concentration lead(II) ions of $0.07 \mathrm{mg} / \mathrm{dm}^{3}$. This concentration of lead in water has been chosen taking into account the chemical composition of the water taken from the Prey Nop area of Cambodia.

Stock solutions of lead(II) (1000 \pm 2 ppm, Buck Scientific, USA) were used for GFAAS calibration. Standard solutions with the required lead(II) ions concentrations were prepared by appropriate dilution with deionized water. The $\mathrm{pH}$ of every solution was maintained at a desired value by adding $0.01 \mathrm{~N} \mathrm{NaOH}$ or $0.01 \mathrm{~N} \mathrm{HNO}_{3}$.

Test water was prepared by dilution stock solution of $\mathrm{Pb}(\mathrm{II})$ in $1 \mathrm{dm}^{3}$ measuring flasks with deionised water. 6 flasks of $1 \mathrm{dm}^{3}$ with $70 \mu \mathrm{g} / \mathrm{dm}^{3} \mathrm{~Pb}$ (II) of test water were used for the tests.

The temperature has the impact on the adsorption process. As the temperature increases, the adsorption process can be activated due to the increased surface area of the sorbent. The optimum temperature for the adsorption process is between 30 and $70{ }^{\circ} \mathrm{C}$ [15].

Experimental adsorption tests were performed at room temperature at $20 \pm 2{ }^{\circ} \mathrm{C}$.

Three sorbents were selected to investigate the adsorption process: clay, sapropel, and iron sludge. Clay from Ukmerge in Lithuania was used for the experiments.

Chemical composition data of the clay [29]

\begin{tabular}{|c|c|}
\hline Compounds & {$[\%] \mathbf{w} / \mathbf{w}$} \\
\hline $\mathrm{SiO}_{2}$ & 66.33 \\
\hline $\mathrm{Al}_{2} \mathrm{O}_{3}$ & 15.8 \\
\hline $\mathrm{Fe}_{2} \mathrm{O}_{3}$ & 6.42 \\
\hline $\mathrm{CaO}$ & 1.8 \\
\hline $\mathrm{MgO}$ & 2.72 \\
\hline $\mathrm{K}_{2} \mathrm{O}$ & 1.63 \\
\hline
\end{tabular}

The raw sapropel was extracted from 2-3 m depth of the Apslavas lake located in Stabulankliai village, Leliunai local municipality, Utena district, Lithuania. The sapropel sample was taken to analyse its composition and to conduct the further experiments. The chemical (elemental) composition of sapropel was investigated by X-ray fluorescence spectrometer with wave variance Axios MAx (manufacturer PANalytical, Netherlands). An X-ray source of $4 \mathrm{~kW}$ power with Rh (rhodium) anode. The chemical composition was calculated using the betalon methodology and software Omnian (PANalytical, Netherlands). The mineral composition was investigated by powder X-ray diffraction 
(Powder X-ray diffraction). Used X-ray diffractometer SmartLab (manufacturer Rigaku, Japan). Analysis was made using the software EVA (Bruker AXS) and X-ray database PDF-2. The carbon content was determined by the Carbon and sulphur analyser CS-2000 (Manufacturer ELTRA, Germany). The composition of sapropel is shown in Table 3.

Table 3

Chemical composition data of the sapropel

\begin{tabular}{|c|c|c|c|}
\hline Element & {$[\%] \mathrm{w} / \mathrm{w}$} & Compound & {$[\%] \mathrm{w} / \mathrm{w}$} \\
\hline $\mathrm{C}$ & 6.616 & $\mathrm{CO}_{2}$ & 24.240 \\
\hline $\mathrm{O}$ & 56.325 & $\mathrm{O}$ & 0.105 \\
\hline $\mathrm{Na}$ & 0.363 & $\mathrm{Na}_{2} \mathrm{O}$ & 0.489 \\
\hline $\mathrm{Mg}$ & 0.279 & $\mathrm{MgO}$ & 0.462 \\
\hline $\mathrm{Al}$ & 2.602 & $\mathrm{Al}_{2} \mathrm{O}_{3}$ & 4.916 \\
\hline $\mathrm{Si}$ & 30.383 & $\mathrm{SiO}_{2}$ & 65.000 \\
\hline$P$ & 0.040 & $\mathrm{P}_{2} \mathrm{O}_{5}$ & 0.091 \\
\hline $\mathrm{S}$ & 0.165 & $\mathrm{SO}_{3}$ & 0.413 \\
\hline $\mathrm{Cl}$ & 0.011 & $\mathrm{Cl}$ & 0.011 \\
\hline $\mathrm{K}$ & 1.422 & $\mathrm{~K}_{2} \mathrm{O}$ & 1.712 \\
\hline $\mathrm{Ca}$ & 0.890 & $\mathrm{CaO}$ & 1.246 \\
\hline $\mathrm{Ti}$ & 0.147 & $\mathrm{TiO}_{2}$ & 0.245 \\
\hline $\mathrm{Cr}$ & 0.027 & $\mathrm{Cr}_{2} \mathrm{O}_{3}$ & 0.040 \\
\hline $\mathrm{Mn}$ & 0.010 & $\mathrm{MnO}$ & 0.013 \\
\hline $\mathrm{Fe}$ & 0.657 & $\mathrm{Fe}_{2} \mathrm{O}_{3}$ & 0.940 \\
\hline $\mathrm{Ni}$ & 0.003 & $\mathrm{NiO}$ & 0.003 \\
\hline $\mathrm{Cu}$ & 0.001 & $\mathrm{CuO}$ & 0.001 \\
\hline $\mathrm{Zn}$ & 0.003 & $\mathrm{ZnO}$ & 0.003 \\
\hline $\mathrm{Rb}$ & 0.005 & $\mathrm{Rb}_{2} \mathrm{O}$ & 0.006 \\
\hline $\mathrm{Sr}$ & 0.005 & $\mathrm{SrO}$ & 0.006 \\
\hline $\mathrm{Y}$ & 0.002 & $\mathrm{Y}_{2} \mathrm{O}_{3}$ & 0.002 \\
\hline $\mathrm{Zr}$ & 0.024 & $\mathrm{ZrO}_{2}$ & 0.032 \\
\hline $\mathrm{Ba}$ & 0.013 & $\mathrm{BaO}$ & 0.015 \\
\hline $\mathrm{Pb}$ & 0.007 & $\mathrm{PbO}$ & 0.008 \\
\hline
\end{tabular}

The iron-saturated slabs from the Antaviliai waterworks, belonging to JSC Vilniaus Vandenys, were used for the tests. An iron sludge pressing machine/filtering press is used in the Antaviliai waterworks. After washing via the open filters, the washing water is filtered and the precipitated iron is compressed and transported to a ceramics factory. Composition data of iron sludge are presented in Table 4.

The sorbents for the adsorption studies were washed twice with deionized water, dried for 3 hours in a drying oven at $110 \pm 2{ }^{\circ} \mathrm{C}$. The dried mass was crushed in a porcelain mortar to a homogeneous mass and spread through a $0.2 \mathrm{~mm}$ sieve.

The efficiency of the removal of lead(II) ions by adsorption depends on the $\mathrm{pH}$ of the solution, the initial concentration of lead ions, the dose of adsorbent, the contact time and temperature [30-32].

Sorbents for adsorption tests were prepared by washing them twice with deionized water, drying for 3 hours in a drying oven at $110 \pm 2{ }^{\circ} \mathrm{C}$ temperature. The dried mass was crushed in a porcelain mortar to a homogeneous mass and sieved through a $0.2 \mathrm{~mm}$ sieve.

The efficiency of the removal of lead(II) ions by adsorption depends on the $\mathrm{pH}$ of the solution, the initial concentration of lead ions, the dose of adsorbent, the contact time and temperature [30, 31]. 
Chemical composition data of iron sludge [28]

\begin{tabular}{|c|c|}
\hline Compounds, elements & {$[\%] \mathbf{w} / \mathbf{w}$} \\
\hline $\mathrm{H}_{2} \mathrm{O}$ & 55 \\
\hline $\mathrm{Fe}$ & 33.9 \\
\hline $\mathrm{Ca}$ & 5.5 \\
\hline $\mathrm{Si}$ & 2.7 \\
\hline $\mathrm{F}$ & 2.2 \\
\hline $\mathrm{Al}$ & 0.4 \\
\hline $\mathrm{Mn}$ & 0.25 \\
\hline$(\mathrm{Zn}, \mathrm{Ba}$, etc. $)$ & 1.05 \\
\hline
\end{tabular}

Dry sorbents - clay, sapropel and iron sludge in the doses of 1, 2, 3, 4, 5 and $6 \mathrm{~g}$ - were weighed with analytical scales. The prepared sorbents were added to the prepared $1 \mathrm{dm}^{3}$ six containers with test water contaminated with lead(II) ions. The test water was mixed with sorbents in a magnetic stirrer at $200 \mathrm{rpm}$ [32].

5 water samples were taken in the quantities of $25 \mathrm{~cm}^{3}$ after different contact times: 30, 60, 90, 120 and $150 \mathrm{~min}$. After adsorption, the solution was filtered through a membrane filter $(47 \mathrm{~mm}$ diameter, pore size $0.45 \mu \mathrm{m})$. After filtration the concentrations of lead(II) ions were determined by using atomic absorption spectrometry (AAS; model Buck Scientific 210 VGP, USA) operated with graphite furnace, a slit of $0.7 \mathrm{~mm}$ at $283.2 \mathrm{~nm}$ wavelength. A chemical modifier $\left(\mathrm{NH}_{4} \mathrm{H}_{2} \mathrm{PO}_{4}\right)$ was used for possible alleviation of matrix interferences, which are normally severe during graphite furnace analysis for lead.

The results were compared with different sorbents: clay, sapropel, iron swabs, and it was found that sapropel was the most effective in the removing of lead(II) ions from the test water. However, the concentration levels were comparatively low - a more detailed study with lower doses of sapropel is required. The second test was designed to determine the conditions under which sapropel adsorbs lead(II) ions best at low doses of sorbent $0.1,0.2,0.4,0.5,0.6,0.8 \mathrm{~g} / \mathrm{dm}^{3}$, and the concentration of lead(II) ions in water was measured after $30,60,90,120$ and 150 minutes.

The analysis sorption efficiency of lead(II) ions in different media had also been performed. Sorption efficiency was tested at $\mathrm{pH} 2,3,4,5,6,7,8,9,10,11,12$. pH was adjusted with $0.01 \mathrm{~N}(\mathrm{HCl})$ and $0.01 \mathrm{~N}(\mathrm{NaOH})$ solutions.

\section{Analysis methods}

Water quality assessment tests after mixing were performed according to the following standards:

- Determination of lead concentration in water was carried out according to LST EN ISO 15586:2004. Water quality - Determination of trace elements using atomic absorption spectrometry with graphite furnace.

- Water pH was determined according to LST ISO 10523:2008 Water quality Examination of water $\mathrm{pH}$.

- According "Council Directive 98/83/EC of 3 November 1998 on the quality of water intended for human consumption" the result is acceptable, when trueness and precision of method is less than $10 \%$.

- Trueness (Table 5) is a measure of systematic error, i.e. the difference between the mean value of the large number (10 measurements) of repeated measurements and the 
true value. Stock solutions of lead(II) is $0.01 \mathrm{mg} / \mathrm{dm}^{3}$ according Council Directive 98/83/EC of 3 November 1998 on the quality of water intended for human consumption parametric value of lead is $10 \mu \mathrm{g} / \mathrm{dm}^{3}$ [8].

- Precision is a measure of random error and is usually expressed as the standard deviation (within and between batches) of the spread of results from the mean. Acceptable precision is twice the relative standard deviation.

Table 5

Trueness and precision of method

\begin{tabular}{|c|c|c|}
\hline & Trueness & Precision \\
\hline Average value $\left[\mu \mathrm{g} / \mathrm{dm}^{3}\right]$ & 9.7 & 10.12 \\
\hline Assigned value $\left[\mu \mathrm{g} / \mathrm{dm}^{3}\right]$ & 10.0 & 10.0 \\
\hline Standard deviation $\left[\mu \mathrm{g} / \mathrm{dm}^{3}\right]$ & 0.24 & 0.39 \\
\hline Relative standard deviation $[\%]$ & 2.4 & 3.9 \\
\hline Acceptable trueness $[\%]$ & 4.8 & 7.8 \\
\hline
\end{tabular}

The obtained result of the analysis is the arithmetical average of concentrations of three samples, when distribution does not exceed $5 \%$, if higher tested were repeated. $95 \%$ confidence interval was calculated.

\section{Results and discussion}

The experiments have determined the dependence of the efficiency of the removal of lead(II) ions from water on the sorbent dose and contact time. The results of the tests are presented in Figures 1-4.

Figure 1 shows that all three sorbents adsorbed lead(II) ions with lead concentration decreasing to $0-11 \mu \mathrm{g} / \mathrm{dm}^{3}$, which corresponds to the cleaning efficiency of 84.3-100\%.

Clay reduced lead(II) ions to $7-9 \mu \mathrm{g} / \mathrm{dm}^{3}$ (87.1-90.0\%). The concentration of lead(II) ions decreased below the permissible value of $10 \mu \mathrm{g} / \mathrm{dm}^{3}$ [8] using all sorbent doses. Using clay, the best results were achieved using the contact time of $30 \mathrm{~min}$ and the quantity of $6 \mathrm{~g}$ : the concentration of lead(II) ions decreased to $7 \mu \mathrm{g} / \mathrm{dm}^{3}(90.0 \%)$ during the testing. Using sapropel, lead(II) ions decreased to $0-4 \mu \mathrm{g} / \mathrm{dm}^{3}(94.3-100 \%$ ) (the value of 0 corresponds to a low concentration that is lower than the device detection limit). Increasing sapropel doses increased the effectiveness of lead removal.

Using all sapropel doses, the concentration of lead(II) ions did not exceed the permissible values of $10 \mu \mathrm{g} / \mathrm{dm}^{3}$ [8]. When using iron sludge, lead(II) ions were reduced to $2-11 \mu \mathrm{g} / \mathrm{dm}^{3}$ (84.3-97.1\%). Using the first two doses ( 1 and $2 \mathrm{~g}$ ), lead(II) ions were above the permissible values, but increasing the sorbent doses led to the decrease in the concentration of lead(II) ions in water and did not exceed the permissible values. By increasing the sorbent dose, the concentration of lead(II) ions decreased.

The results obtained show that the lead ion concentration decreased from $70 \mu \mathrm{g} / \mathrm{dm}^{3}$ to $0-12 \mu \mathrm{g} / \mathrm{dm}^{3}(82.9-100 \%)$ at $60 \mathrm{~min}$ contact (Fig. 2). Clay reduced the concentration of lead(II) ions to $8-12 \mu \mathrm{g} / \mathrm{dm}^{3}$ (82.9-88.6 \%). Lead(II) ions had fallen below the permissible value of $10 \mu \mathrm{g} / \mathrm{dm}^{3}$ [8] with 2, 3 and $5 \mathrm{~g}$ adsorbent doses. Using clay, the best results were achieved with the $60 \mathrm{~min}$ contact time and $2 \mathrm{~g}$ of adsorbent when the concentration of lead(II) ions decreased to $8 \mu \mathrm{g} / \mathrm{dm}^{3}(88.6 \%)$. Using sapropel the concentration of lead(II) 
ions dropped to $0 \mu \mathrm{g} / \mathrm{dm}^{3}$ (100\%) (value 0 corresponds to a low concentration that is lower than the device detection limit).

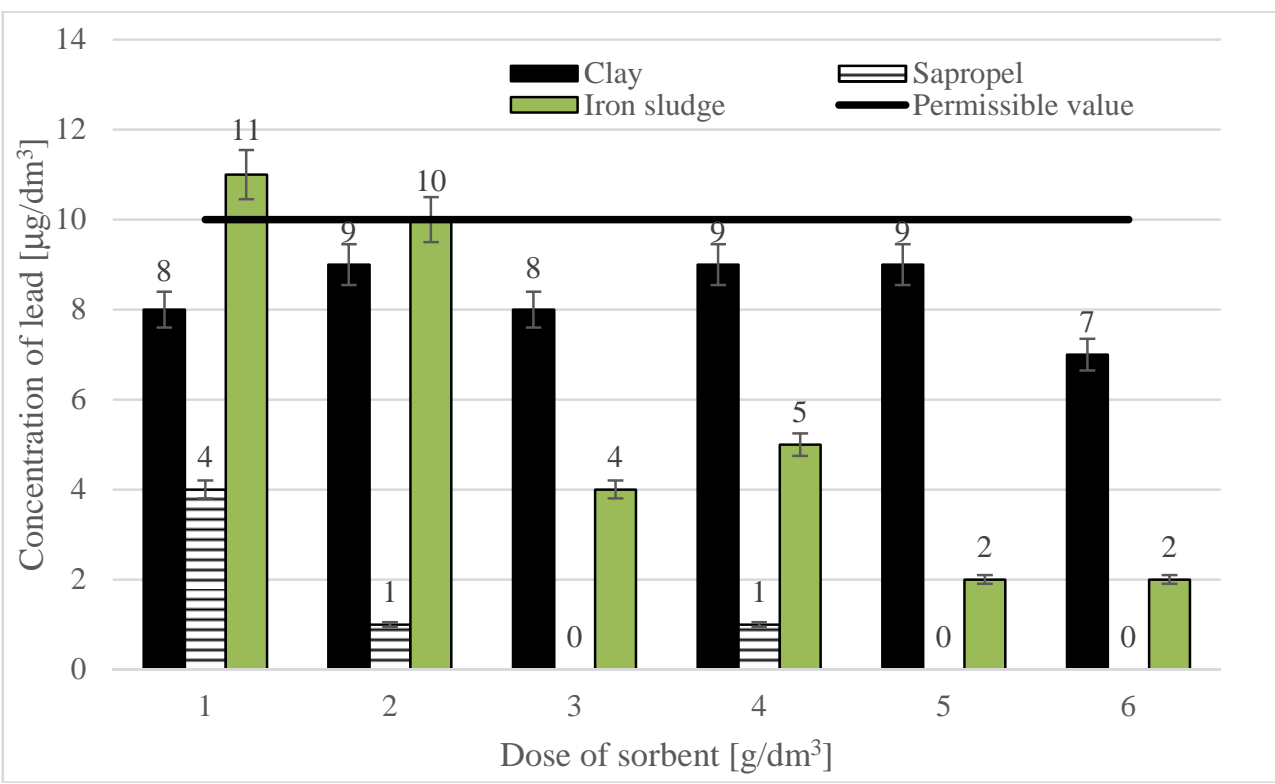

Fig. 1. Lead(II) concentration dependence on different amount of sorbents, at 30 min contact time

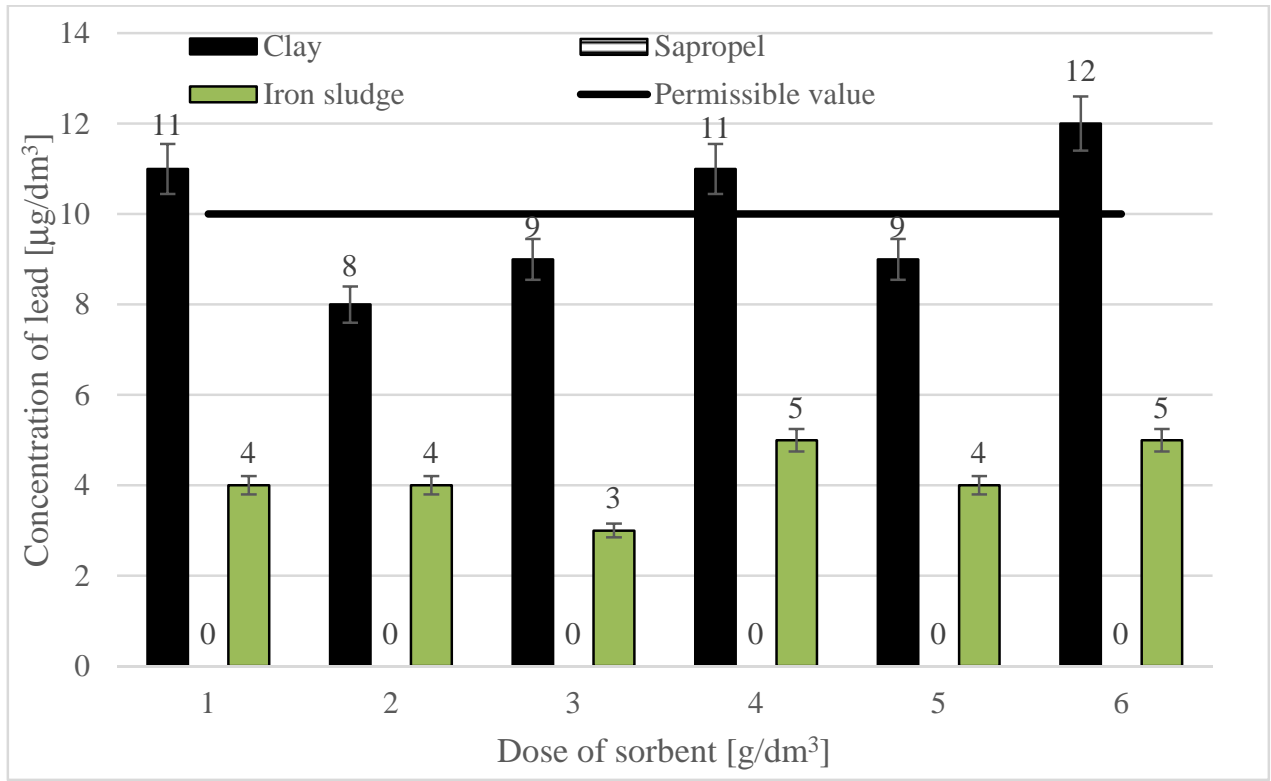

Fig. 2. Lead(II) concentration dependence on different amount of sorbents, at 60 min contact time 
Using all the doses of sapropel the maximum cleaning efficiency was achieved. When using iron sludge, lead(II) ions were reduced to $3-5 \mu \mathrm{g} / \mathrm{dm}^{3}(92.9-95.7 \%)$. For all doses of iron, the concentration of lead(II) ions did not exceed the permissible value of $10 \mu \mathrm{g} / \mathrm{dm}^{3}$ [8]. By increasing the amount of sorbent, the concentration of lead(II) in the solution was practically unchanged.

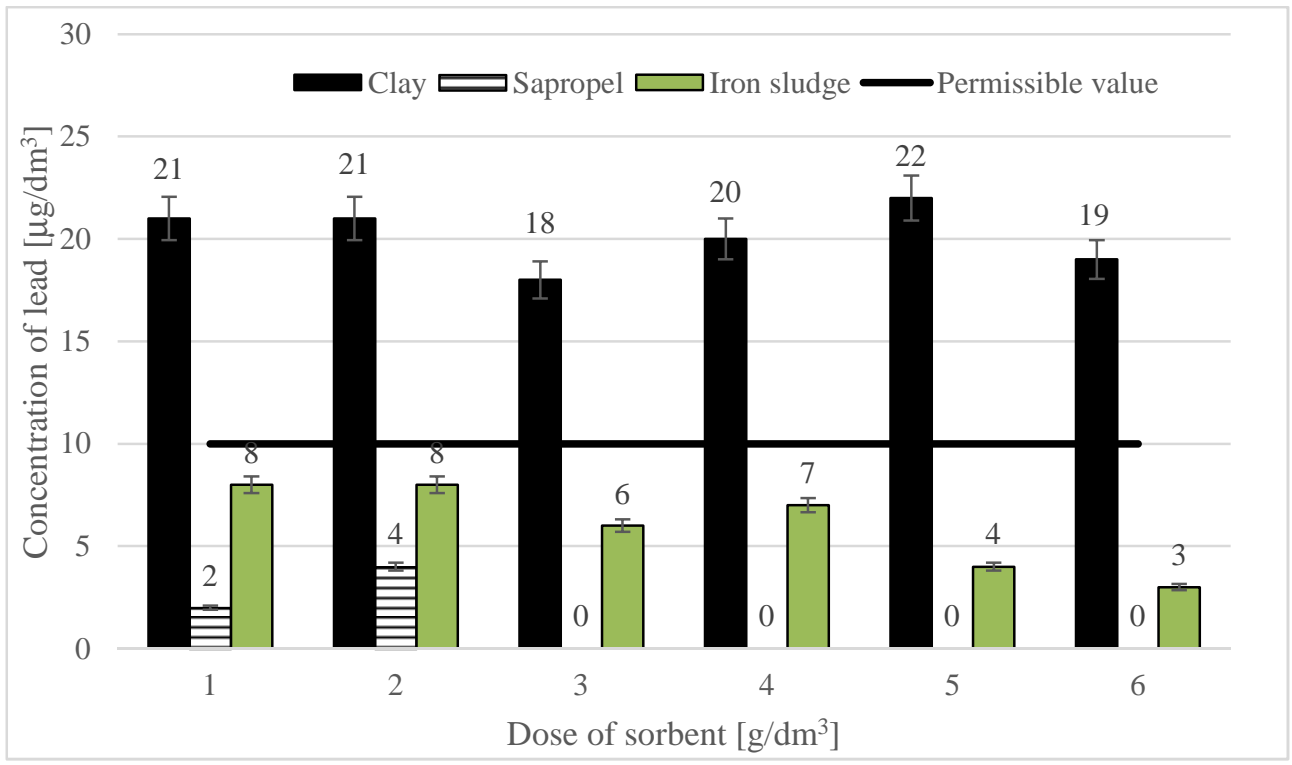

Fig. 3. Lead(II) concentration dependence on different amount of sorbents, at 90 min contact time

The results in Figure 3 show that the use of three different sorbents reduced the concentration of lead(II) ions to $0-22 \mu \mathrm{g} / \mathrm{dm}^{3}$ (68.6-100 \%). Using clay, lead(II) ions were reduced to $18-22 \mu \mathrm{g} / \mathrm{dm}^{3}$ (68.6-74.3\%), but did not decrease to the permissible value of $10 \mu \mathrm{g} / \mathrm{dm}^{3}$ for all clay doses. By increasing clay doses, the concentration of lead(II) ions remained practically stable. The results show that the increase of the sorption time of the clay reduced the sorption capacity of the clay. Clay still adsorbed lead(II) ions but was no longer as effective as during the mixing for 30 and 60 minutes. Using sapropel, lead(II) ions were reduced to $0-4 \mu \mathrm{g} / \mathrm{dm}^{3}$ (94.3-100 \%) and iron sludge - to $3-8 \mu \mathrm{g} / \mathrm{dm}^{3}$ (88.6-95.7 \%). Using these two sorbents, the concentration of lead(II) ions decreased below the permissible value using all sorbent doses. By increasing the doses of sorbents (sapropel and iron sludge), lead(II) ions were reduced, but the sapropel reduced lead more effectively.

Figure 4 shows that after 120 min contact time the concentration of lead(II) ions decreased to $0-24 \mu \mathrm{g} / \mathrm{dm}^{3}(65.7-100 \%)$. Clay reduced lead(II) ions to $19-24 \mu \mathrm{g} / \mathrm{dm}^{3}$ (65.7-72.9\%), but did not reduce it to the permissible value. By increasing clay doses, the concentration of lead(II) ions was practically unchanged. Using sapropel, the concentration of lead(II) ion decreased to $0 \mu \mathrm{g} / \mathrm{dm}^{3}$, the lead removal efficiency was at maximum. Using iron sludge, the concentration of lead(II) ions in water was reduced to $2-4 \mu \mathrm{g} / \mathrm{dm}^{3}$ (94.3-97.1\%). The concentration of lead(II) ions decreased below the permissible value of 
$10 \mu \mathrm{g} / \mathrm{dm}^{3}$ [8]. The concentration of lead(II) ions was practically unchanged when increasing iron sludge doses.

After the sorption testing with three sorbents (clay, sapropel and iron sludge), it was observed that all three sorbents reduced the concentration of lead(II) ions in water. Clay is the most effective in adsorbing lead when its contact time is the lowest, i.e., of 30 minutes. By prolonging the contact time, it still removed lead(II) ions, but the removal efficiency was reduced and the removal of lead(II) ions did not fall below the $10 \mu \mathrm{g} / \mathrm{dm}^{3}$ value [8].

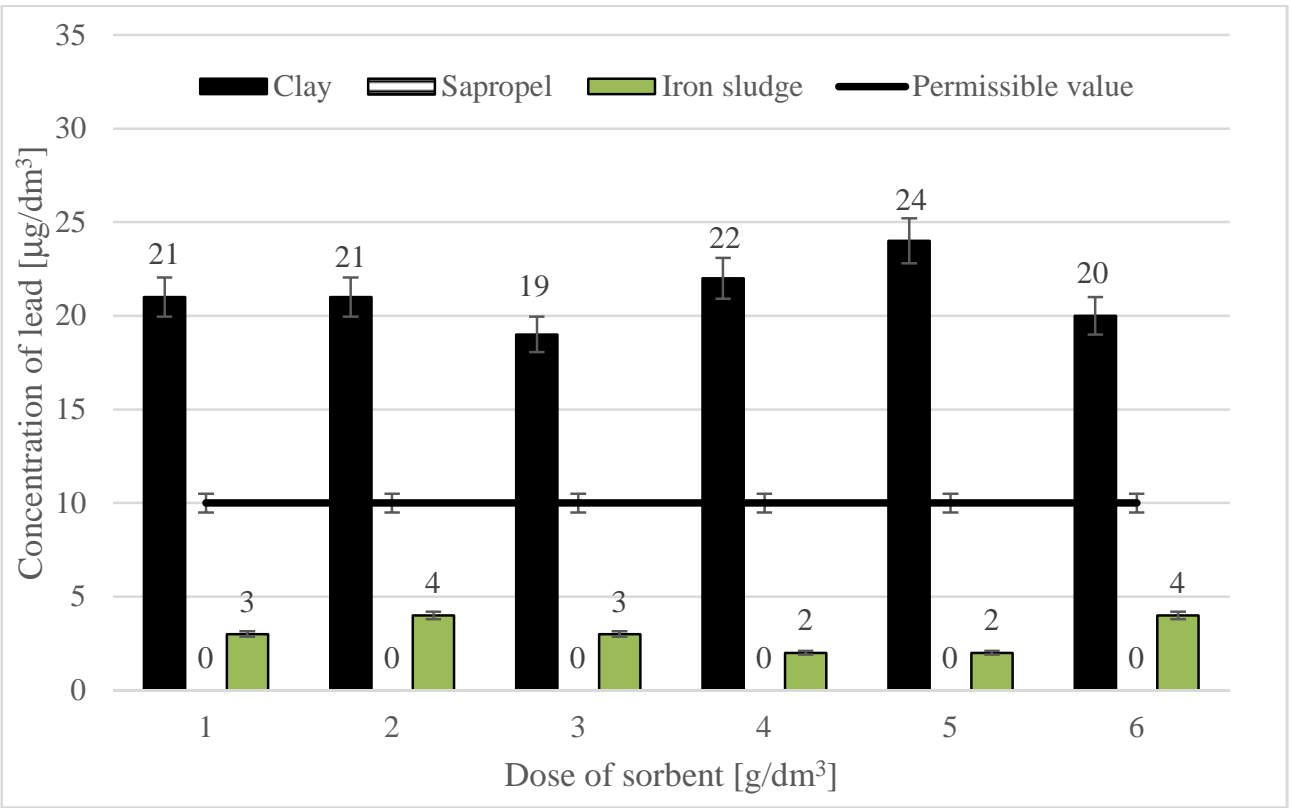

Fig. 4. Lead(II) concentration dependence on different amount of sorbents, at 120 min contact time

When using the iron sludge, the process was opposite: with the shortest contact time, lead removal took place with the lowest efficiency, but with higher doses of iron sludge (3, 4, 5 and $6 \mathrm{~g} / \mathrm{dm}^{3}$ ) and after $30 \mathrm{~min}$ contact time, the concentration the lead(II) ions decreased below the permissible limit values. Increasing contact time increased the efficiency of the removal of lead(II) ions, but the removal efficiency was practically independent of dose.

Using sapropel, lead(II) ions were efficiently removed using all sorbent doses and all contact times. By prolonging the contact time, the sapropel sorption capacity did not decrease.

Similar results were obtained by other scientists when assessing the influence of contact time on the adsorption of lead(II) ions. The optimum contact time between sorbent and lead(II) ions is 30-90 minutes [20, 32, 15].

When tested with different sorbents, at different doses, at different contact times, the sorption capacity of each sorbent can be calculated by the formula:

$$
q_{e}=\frac{\left(C_{0}-C_{e}\right) V}{W} \cdot 100
$$


where $q_{e}$ is the amount of adsorption [mg/g]. $C_{0}$ and $C_{e}$ are the lead(II) ions concentrations initial and after adsorption $\left[\mathrm{mg} / \mathrm{dm}^{3}\right]$, respectively. $V$ is the volume of the solution $\left[\mathrm{dm}^{3}\right]$, $W$ is the mass of adsorbent $[\mathrm{g}]$.

Clay sorption capacity using $1 \mathrm{~g}$ of clay at different contact times ranges from 4.9 to $6.2 \mathrm{mg} / \mathrm{g}$. The sorption capacity of iron sludge ranges from 5.9 to $6.7 \mathrm{mg} / \mathrm{g}$ and sapropel from 6.6 to $7.0 \mathrm{mg} / \mathrm{g}$.

The results were compared with different sorbents: clay, sapropel, iron sludge, and it was found that sapropel was the most effective in removing lead(II) ions from the test water. Using sapropel, the efficiency of removing lead ions reached 94.3-100\%. Therefore, it was decided to conduct studies using lower doses of sapropel $\left(0.1,0.2,0.4,0.5,0.6 \mathrm{~g} / \mathrm{dm}^{3}\right.$ and $0.8 \mathrm{~g} / \mathrm{dm}^{3}$ ).

Figure 5 shows the dependence the concentration of lead(II) ions in the solution on different doses of sapropel at 30 minutes of contact time.

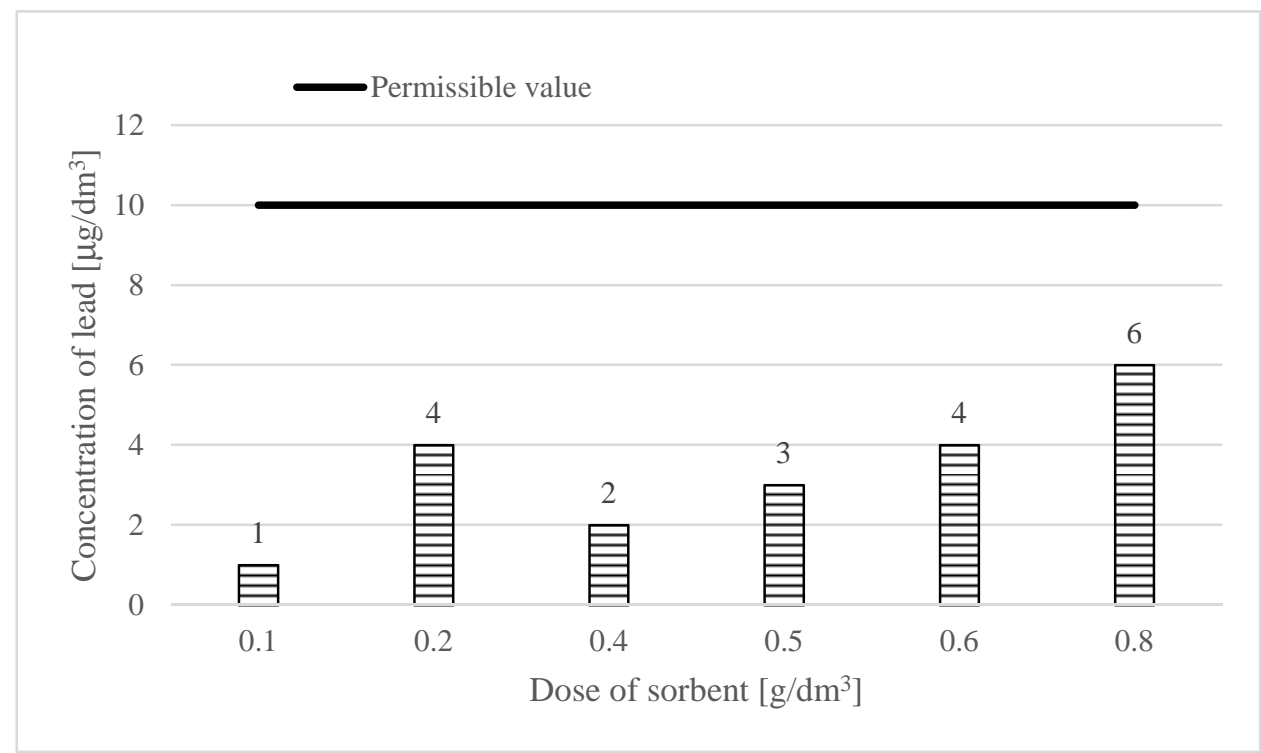

Fig. 5. Lead(II) concentration dependence on different amount of sapropel, at 30 min contact time

Figure 5 shows that the concentration of lead(II) ions decreased from $70 \mu \mathrm{g} / \mathrm{dm}^{3}$ to 1-6 $\mu \mathrm{g} / \mathrm{dm}^{3}$, water treatment efficiency reached $90.9-98.7 \%$. The concentration of lead(II) ions decreased below the permissible limit of $10 \mu \mathrm{g} / \mathrm{dm}^{3}$ [8] using $0.1-0.8 \mathrm{~g} / \mathrm{dm}^{3}$ sapropel doses. The best results were achieved with the lowest amount of sapropel, i.e. of $0.1 \mathrm{~g} / \mathrm{dm}^{3}$, with lead(II) concentration decreasing to $1 \mu \mathrm{g} / \mathrm{dm}^{3}(98.7 \%)$.

Figure 6 shows the concentration of lead(II) ions in different sapropel doses after 60 min of contact time.

The results show that with the 60 min contact, the lead(II) ion concentration decreased from $70 \mu \mathrm{g} / \mathrm{dm}^{3}$ to $1-2 \mu \mathrm{g} / \mathrm{dm}^{3}$ (96.7-98.3 \%), the lead(II) concentration decreased below the permissible value. Using different doses of sapropel, the effectiveness of the removal of lead(II) ions was virtually unchanged. 


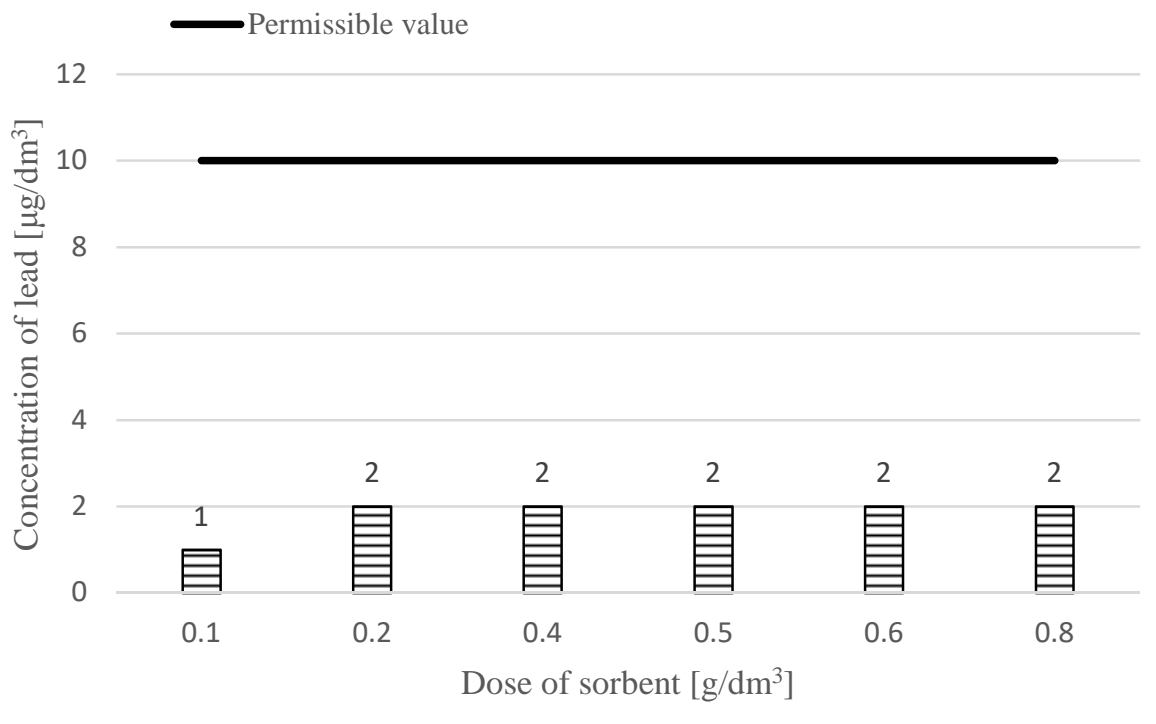

Fig. 6. Lead(II) concentration dependence on different amount of sapropel, at 60 min contact time $\mu$

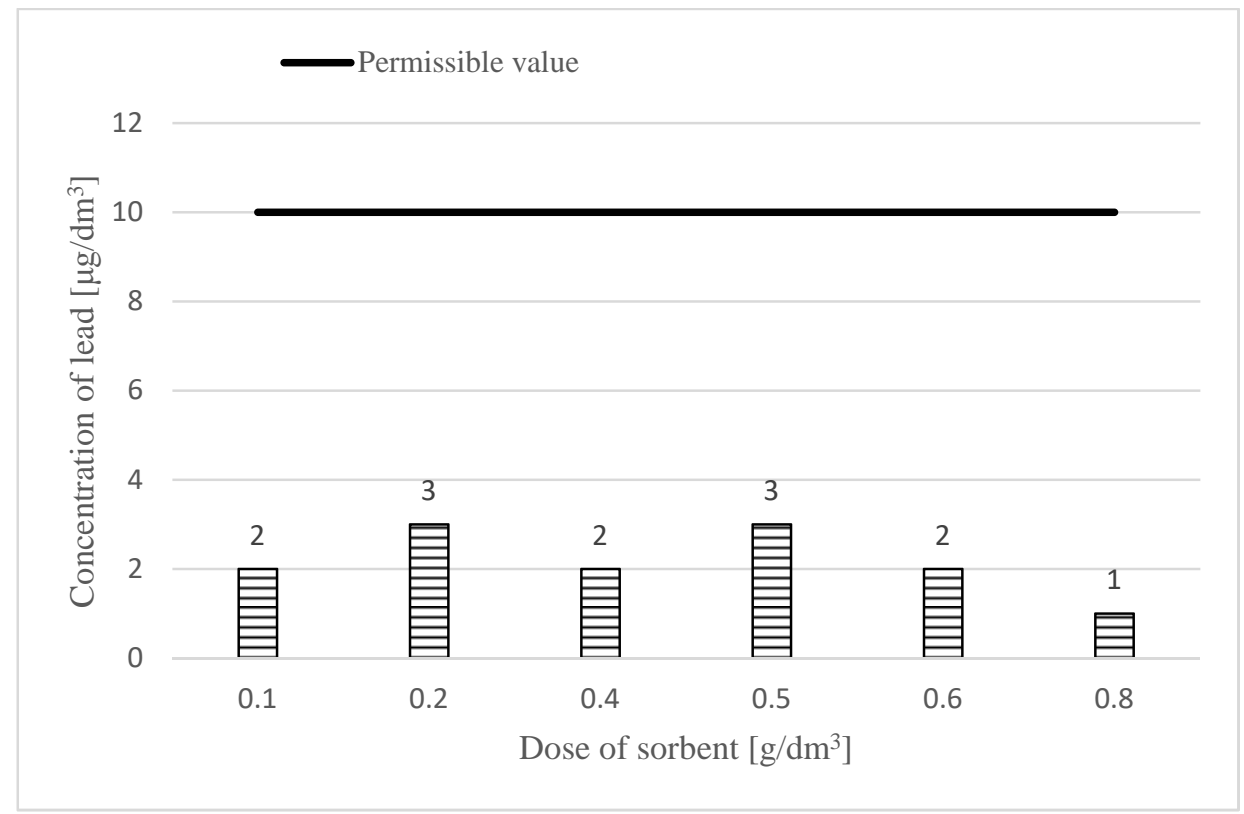

Fig. 7. Lead(II) concentration dependence on different amount of sapropel, at 90 min contact time

Figure 7 presents the concentration of lead(II) ions in different sapropel doses at 90 minutes of contact time. 
Figure 7 shows how the concentration of lead(II) ions decreased to $1-3 \mu \mathrm{g} / \mathrm{dm}^{3}$ (92.0-98.1\%) after 90 min contact time. In this case, the concentration of lead(II) ions after sorption was also lower than the permissible limit value. By increasing the doses of sapropel, the concentration of lead(II) fluctuated within a very small range. Figure 8 shows the concentration of lead(II) ions in different sapropel doses at 120 minutes of contact time.

The results in Figure 8 show that the concentration of lead(II) ions was reduced to 1-4 $\mu \mathrm{g} / \mathrm{dm}^{3}$ (93.1-98.6\%). Using this sorbent, the concentration of lead(II) ions decreased below the permissible value for all sapropel doses. By increasing the doses of sapropel, the concentration of lead(II) ions fluctuated within a very small range.

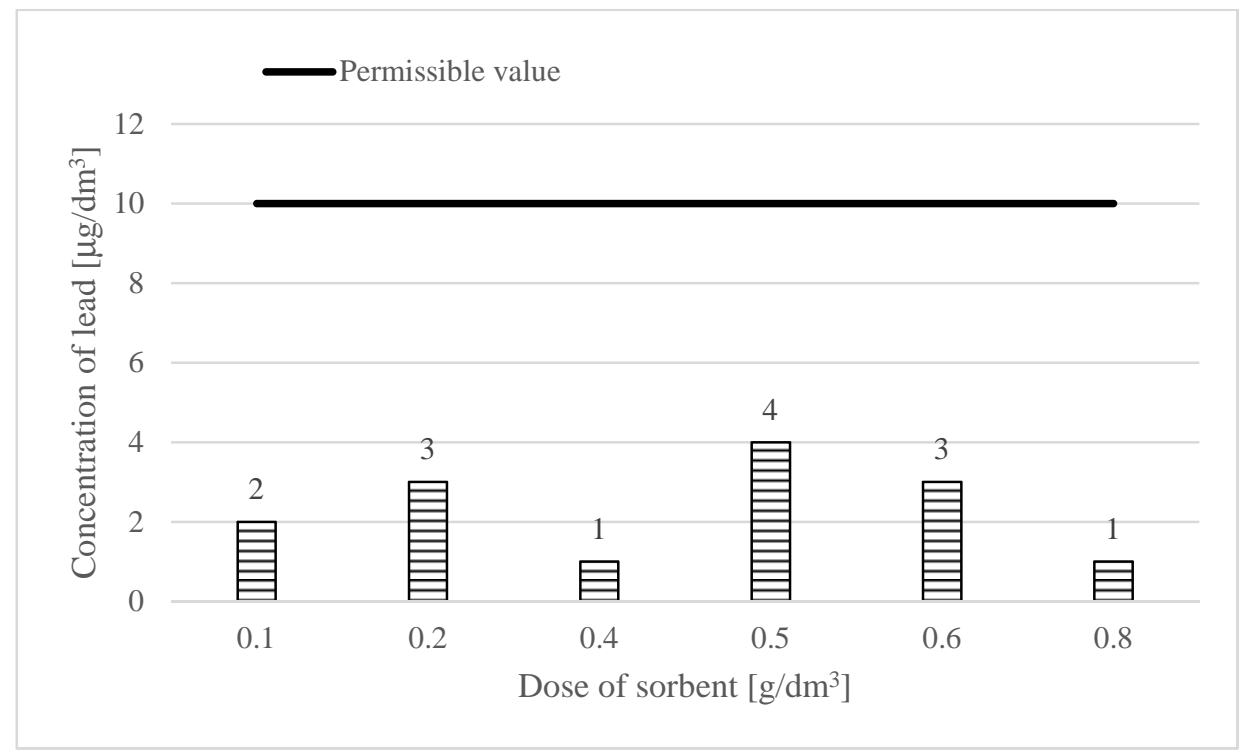

Fig. 8. Lead(II) concentration dependence on different amount of sapropel, at 120 min contact time

The sorbent dose had a significant effect on the efficiency of adsorption of lead ions. In the presence of excess adsorbent, aggregation, which reduces the adsorption surface and adsorption capacity $[14,27]$ is possible, thus the optimum adsorbent dose is to be set during the adsorption process. After conducting experimental tests with low doses of sapropel, it was found that lead(II) ions were removed from contaminated water by all sapropel doses used. Because all tested doses of sapropel effectively removed lead(II) ions, it is the best to use the lowest dose of $0.1 \mathrm{~g} / \mathrm{dm}^{3}$. Using this sapropel dose, the sapropel sorption capacity is $69 \mathrm{mg} / \mathrm{g}$.

Figure 9 shows the dependency of the concentration of lead(II) ions on the contact time with the use of $0.1 \mathrm{~g} / \mathrm{dm}^{3}$ sapropel.

Figure 9 shows that by removing lead(II) ions from the test water with sapropel, both after 30 minutes and 120 minutes the concentration of lead(II) in water decreased efficiently and the concentration of lead(II) did not exceed the permissible limit value. It was also found that the optimal adsorption time is $30 \mathrm{~min}$, with the concentration of lead(II) ions in water decreasing to $1 \mu \mathrm{g} / \mathrm{dm}^{3}(98.7 \%)$. 


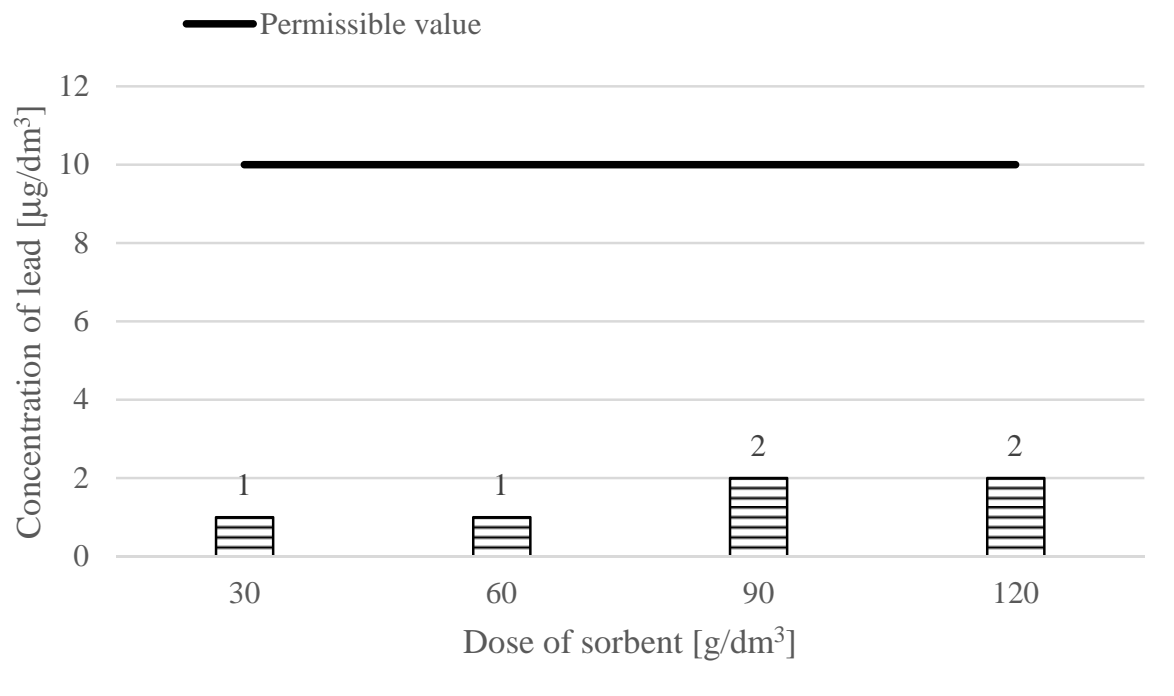

Fig. 9. Concentration of lead(II) ions at different contact times using $0.1 \mathrm{~g} / \mathrm{dm}^{3}$ sapropel

In the first stages of the testing, the most effective sorbent and optimal adsorption conditions - the optimal amount of sorbent and contact time - were identified, and later on the influence of $\mathrm{pH}$ on adsorption of lead(II) ions was analysed. Based on previous studies, other optimal conditions for the removal of lead(II) ions from the test water were chosen: the optimal dose of sorbent (sapropel) was $0.1 \mathrm{~g} / \mathrm{dm}^{3}$, the optimum contact time was 30 minutes. Using this optimal dose and the contact time, the $\mathrm{pH}$ of the solution was changed. $\mathrm{pH}$ is one of the most important environmental factors influencing not only site dissociation, but also the solution chemistry of the heavy metal: hydrolysis, complexation by organic and/or inorganic ligands, redox reactions, and precipitation are strongly influenced by $\mathrm{pH}$ and, on the other hand, it strongly influences the speciation and adsorption availability of heavy metals. The adsorption process is highly dependent on the $\mathrm{pH}$ of the medium. When the $\mathrm{pH}$ medium changes, forms of a sorbent and metal ions also change [14].

The results of the testing when changing the $\mathrm{pH}$ of the solution are presented in Figure 10.

Figure 10 shows that the concentration of lead(II) ions decreased from $70 \mu \mathrm{g} / \mathrm{dm}^{3}$ to 1-15 $\mu \mathrm{g} / \mathrm{dm}^{3}$ (adsorption efficiency of 78.6-99\%). Lead(II) ions were the most effectively removed when the $\mathrm{pH}$ was strongly acidic $(\mathrm{pH}=2)$. Lead(II) ions were not removed from water when the $\mathrm{pH}$ was lower than 3.0 , because $\mathrm{H}^{+}$ions inhibit the adsorption process.

The reduction of the concentration of lead(II) ions was $78.6 \%$, but the concentration did not fall to the permissible limit value. By increasing the $\mathrm{pH}$ of the solution from 3 to 5 , the efficiency of the removal of lead ions increased (91.4-94.3\%) and lead(II) concentrations no longer exceeded the permissible values.

The increase in adsorption capacity of lead(II) ions with increasing $\mathrm{pH}$ is the result of two possible mechanisms, which are cation exchange, and surface complexation mechanisms [26]. 
High lead(II) ions removal efficiency when $\mathrm{pH}=7-12$ can be explained by lead hydroxides formation at $\mathrm{pH}>6.5$ for $\mathrm{Pb}(\mathrm{OH})_{2}$, especially when $\mathrm{pH}>8$ [33].

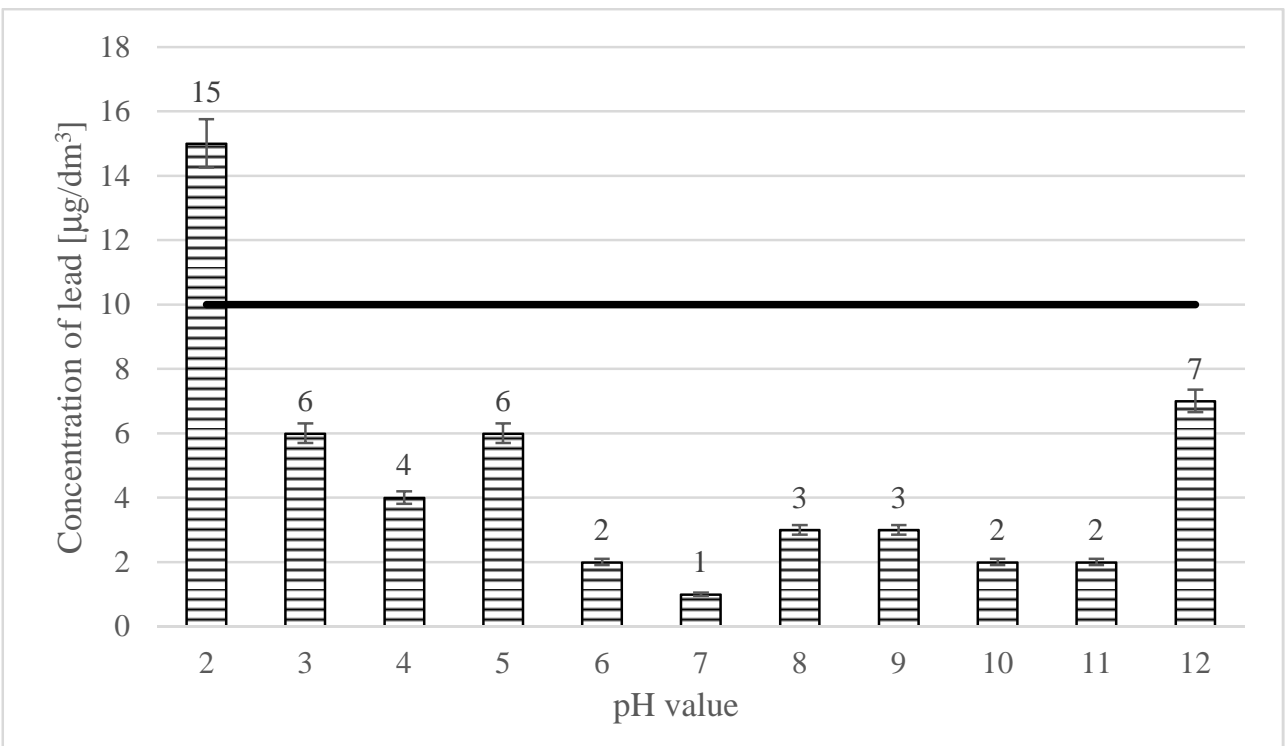

Fig. 10. Concentration of lead(II) ions at different $\mathrm{pH}$ values of the solution using $0.1 \mathrm{~g} / \mathrm{dm}^{3}$ sapropel, contact time $30 \mathrm{~min}$

The most effective removal of lead(II) ions occurred when the $\mathrm{pH}$ of the solution was between 6 and 11. The efficiency of the removal of lead(II) ions was reduced to $90 \%$ by increasing the $\mathrm{pH}$ to 12 , but the concentration of lead ions still did not exceed the permissible values. The high efficiency of the removal lead(II) ions can be explained by adsorption and formation of insoluble $\mathrm{Pb}(\mathrm{OH})_{2}$ sediments.

The adsorption testing at different $\mathrm{pH}$ have shown that the optimum $\mathrm{pH}$ for the adsorption of lead(II) ions is about 6.0. Other researchers also received similar results. The optimum $\mathrm{pH}$ for effective adsorption is between 3.0 and 6.0 [20, 32].

Adsorbents can be used repeatedly when selecting the appropriate desorption process, used as fertilizer or to be disposed in accordance with the regulations governing waste management in the Republic of Lithuania.

\section{Conclusion}

1. All three investigated sorbents reduce the concentration of lead(II) ions in water: clay by $65.7-90 \%$, sapropel by $94.3-100 \%$, and iron sludge by $84.3-97 \%$, depending on sorbent type and contact duration.

2. Clay was found to be the most effective in the removing of lead(II) ions at the shortest adsorption time - $30 \mathrm{~min}$. In this case the concentration of lead(II) ions decreased to $7-9 \mu \mathrm{g} / \mathrm{dm}^{3}(87.1-90.0 \%)$. Lead was the most effectively removed $(90.0 \%)$ using the sorbent dose of $6 \mathrm{~g} / \mathrm{dm}^{3}$. 
3. Using iron sludge at the shortest contact time of $30 \mathrm{~min}$, the removal of lead(II) ions was performed with the lowest efficiency, but with higher doses of iron sludge $(3,4,5$ and $6 \mathrm{~g} / \mathrm{dm}^{3}$ ) and at the contact time of 30 minutes, the concentration of lead(II) ions decreased below the permissible value. Increasing contact time increased the efficiency of the removal of lead(II) ion, but the removal efficiency is practically independent of the dose of adsorbent. When the contact time was 60 minutes, the concentration of lead(II) ions no longer exceeded the permissible limits.

4. Experimental testing had shown that the most effective way to remove lead(II) ions from the test water is sapropel. Using sapropel, the treatment efficiency of water, contaminated with lead(II) ions, reached 94.3-100\% using different sorbent doses $\left(1,2,3,4,5,6 \mathrm{~g} / \mathrm{dm}^{3}\right)$ and at different adsorption times. The concentration of lead(II) ions in the test water after purification did not exceed the permissible limits $\left(10 \mu \mathrm{g} / \mathrm{dm}^{3}\right)$.

5. Experimental testing with low doses of sapropel $\left(0.1,0.2,0.4,0.5,0.6,0.8 \mathrm{~g} / \mathrm{dm}^{3}\right) \mathrm{had}$ shown that all used sapropel doses effectively eliminate lead(II) ions, so it is the best to use the lowest dose of $0.1 \mathrm{~g} / \mathrm{dm}^{3}$. The concentration of lead ions decreased to $1-2 \mu \mathrm{g} / \mathrm{dm}^{3}$ (95.4-98.6\%) and did not exceed the allowable drinking water standards $\left(10 \mu \mathrm{g} / \mathrm{dm}^{3}\right)$ according to Directive 98/83/EC [8] after treatment.

6. Experimental testing had led to the identification of the optimal conditions for the removal of lead ions from contaminated water: at the dose of sapropel being $0.1 \mathrm{~g} / \mathrm{dm}^{3}$, the contact time - $30 \mathrm{~min}$ and with $\mathrm{pH}=7$, the concentration of lead(II) in water decreased from 70 to $1 \mu \mathrm{g} / \mathrm{dm}^{3}(\sim 99 \%)$.

\section{References}

[1] Akers DB, MacCarthy MF, Cunningham JA, Annis J, Mihelcic JR. Environ Sci Technol. 2015;5:2685-93. DOI: $10.1021 /$ es504517r.

[2] Wani AL, Ara A, Usmani JA. Interdiscip Toxicol. 2015;2:55-64. DOI: 10.1515/intox-2015-0009.

[3] Schamphelaere KAC, Nys C, Janssen CR. Aquat Toxicol. 2014;155:348-59. DOI: 10.1016/j.aquatox.2014.07.008.

[4] Liu G, Yu Y, Hou J, Xue W, Liu X, Liu Y, et al. Ecol Indic. 2014;47:210-8. DOI: 10.1016/j.ecolind.2014.04.040.

[5] Zhang R, Wilson VL, Hou A, Meng G. Int J Health Anim Sci Food Saf. 2015;1:18-31. DOI: $10.13130 / 2283-3927 / 4785$.

[6] Woolf AD, Goldman R, Bellinger DC. Pediatr Clin North Am. 2007;2:271-94. DOI: 10.1016/j.pcl.2007.01.008.

[7] Zhang Y, Wang X, Chen H, Yang X, Chen J, Allen JO. Chemosphere. 2009;74:501-7. DOI: 10.1016/j.chemosphere.2008.10.004.

[8] Council Directive 98/83/EC of 3 November 1998. On the quality of water intended for human consumption. https://eur-lex.europa.eu/legal-content/EN/TXT/?uri=CELEX\%3A31998L0083.

[9] Chen M, Lee JM, Nurhati IS, Switzer AD, Boyle EA. Mar Chem. 2015;168:49-59. DOI: 10.1016/j.marchem.2014.10.007.

[10] Li P, Lin C, Cheng H, Duan X, Lei K. Ecotoxicol Environ Saf. 2015;113:391-9. DOI: 10.1016/j.ecoenv.2014.12.025.

[11] Lu L, Cheng H, Liu X, Xie J, Li Q, Zhou T. PLoS One. 2015;3:e0119562. DOI: 10.1371/journal.pone.0119562.

[12] Gholami A, Moghadassi AR, Hosseini SM, Shabani S, Gholami F. J Ind Eng Chem. 2014;4:1517-22. DOI: 10.5829/idosi.ije.2016.29.03c.01.

[13] Bhatia M, Satish Babu R, Sonawane SH, Gogate PR, Girdhar A, Reddy ER, et al. Int J Environ Sci Technol. 2016;1-20. DOI: 10.1007/s13762-016-1198-6.

[14] Ngulube T, Ray J, Masindi V, Maity A. J Environ Manage. 2017;191:35-57. DOI: 10.1016/j.jenvman.2016.12.031. 
[15] Badawi MA, Negm NA, Abou Kana MT, Abdel Moneem MM. Int J Biol Macromol. 2017;99:465-76. DOI: 10.1016/j.ijbiomac.2017.03.003.

[16] Golbad S, Khoshnoud P, Abu-Zahra N. Int J Environ Sci Technol. 2017;1:135-42. DOI: 10.1007/s13762-016-1133-x.

[17] Zou Ch, Jiang W, Sun X, Guan Y. Environ Sci Pollut Res. 2019;26:1315-22. DOI: 10.1007/s11356-018-3652-0.

[18] Kocaoba S, Arisoy M. Separ Sci Technol. 2018;11:1703-10. DOI: 10.1080/01496395.2018.1442477.

[19] Bailey SE, Olin TJ, Bricka MR, Adrian DD. Water Resour. 1999;33:2469-79. DOI: 10.1016/S0043-1354(98)00475-8.

[20] Mishra PC, Patel RK. J Hazard Mater. 2009;1:319-25. DOI: 10.1016/j.jhazmat.2009.02.026.

[21] Alhogbi BG, Salam MA, Ibrahim O. Desal Water Treat. 2019;145:179-88. DOI: 10.5004/dwt.2019.23507.

[22] Khohsang H, Ghaffarinejad A. J Environ Chem Eng. 2018;5:6021-7. DOI: 10.1016/j.jece.2018.09.020.

[23] Elmoubarki R, Mahjoubi FZ, Tounsadi H, Moustadraf J. Water Resour Ind. 2015;9:16-29. DOI: 10.1016/j.wri.2014.11.001.

[24] Yan L, Qin L, Yu H, Li S, Shan R, Du B. J Mol Liq. 2015;11:1074-81. DOI: 10.1016/j.molliq.2015.08.032.

[25] Santos SCR, Boaventura RAR. J Chem Eng. 2016;2:1473-83. DOI: 10.1016/j.jece.2016.02.009.

[26] Bakšiene E, Ciūnys A. J Environ Eng Land Manage. 2012;(2):97-103. DOI: 10.3846/16486897.2011.645824.

[27] Adeeva LN, Kovalenko TA. Russ. J Appl Chem. 2012;85(4):557-63. DOI: 10.1134/S1070427212040040.

[28] Albrektienè R, Karaliūnas K, Bazienè K. Sustain. 2019;11(3):1-15. DOI: 10.3390/su11030639.

[29] Žurauskienė R, Mačiulaitis R, Petrikaitis F. J Civil Eng Manage. 2001;7(3):191-6. DOI: 10.3846/13921525.2001.10531723.

[30] Liu Y, Xiao D, Li H. Sep Sci Technol. 2007;1:185-202. DOI: 10.1080/01496390600998045.

[31] Fan C, Du B, Zhang Y, Gao Y, Chang M. J Geochem Explor. 2017;176:50-6. DOI: 10.1016/j.gexplo.2016.02.012.

[32] Gerçel Ö, Gerçel H. Chem Eng J. 2007;1:289-97. DOI: 10.1016/j.cej.2007.01.010.

[33] Wan MW, Kan CC, Rogel BD, Dalida MLP. Carbohydr Polym. 2010;3:891-9. DOI: 10.1016/j.carbpol.2009.12.048. 